\title{
РОЗРОБЛЕННЯ СИСТЕМИ АНАЛІЗУ ТРАНСДИСЦИПЛІНАРНИХ ДАНИХ В ГАЛУЗІ ФІЗИЧНОЇ ТА РЕАБІЛІТАЦІЙНОЇ МЕДИЦИНИ (ФРМ)
}

\author{
Надутенко М. В.
}

\author{
Украӥнський мовно-інформаційний фонд НАН Украӥни, м. Київ, Украӥна
}

Для кореспонденції: Надутенко Максим Вікторович, кандидат технічних наук, завідувач відділу інформатики, Український мовно-інформаційний фонд НАН України, пр-т. Голосіївський, 3, м. Київ, 03039, Україна; факс: +38 (044) 525-86-75; e-mail: maxkrb@gmail.com.

\begin{abstract}
Реабілітація $є$ важливою складовою системи охорони здоров’я. Проблема реабілітації хворих під час пандемії COVID-19 спричиненої вірусом SARS-CoV-2 на сьогодні є надзвичайно актуальною не тільки в Україні, а й у всьому світі. Методики ж реабілітації хворих після перенесеної хвороби COVID-19 на сьогодні, у більшості випадків є не розробленими. В Україні одним із завдань викладених у затвердженій нещодавно Стратегії людського розвитку є впровадження ефективної системи реабілітації на основі єдиних стандартів. Однак нормативна база пов'язана з питаннями реабілітації перебуває в стадії становлення. Таким чином виникає проблема створення систем з підтримки досліджень в галузі реабілітації, які би враховували велику кількість неоднорідних даних та граничних умов, що можуть змінюватися.

Одним із механізмів створення таких інформаційних систем є принцип відкритих онтологій, який зараз рекомендується провідними країнами світу для забезпечення семантичної інтеграції розподілених інформаційних систем різного типу.

Мета дослідження полягала в розробленні технології спрямованої на вирішення проблеми інтеграції розподілених трансдисциплінарних даних в галузі фізичної та реабілітаційної медицини на основі онтологічного підходу.

Більшість трансдисциплінарних даних в галузі фізичної та реабілітаційної медицини є документами написаними природною мовою Оскільки в мовленнєвому потоці онтологічна природа мови виступає неподільною на окремі складові частини, які є в концептуальних представленнях, то для формалізованого опису діяльності експерта-реабілітолога необхідним є використання комплексних («інтегрованих») моделей мовних явищ та корпусних технологій Методологічною основою корпусних лексикографічних технологій є теорія семантичних станів, на основі якої здійснюється семантико-синтаксичний аналіз природномовних об'єктів в трансдисциплінарних даних.

Описаний підхід дає можливість створити необхідне середовище для обробки та збереження інформаційних ресурсів у галузі фізичної та реабілітаційної медицини та здійснити його індексування. Засоби індексування ФРМ забезпечують відображення трансдисциплінарних семантично пов'язаних контекстів в результаті обміну інформацією між розподіленими трансдисциплінарними інформаційними ресурсами. Система індексування інформаційних ресурсів у галузі ФРМ акумулює функціональні можливості сервісів інших інформаційно-лексикографічних систем, а саме - електронної бібліотеки, граматичного словника, а також функцій повнотекстового пошуку.

Проведене дослідження дає можливість створення технології спрямованої на вирішення проблеми інтеграції розподілених трансдисциплінарних даних в галузі фізичної та реабілітаційної медицини на основі онтологічного підходу Зазначений підхід дозволяє швидко розгорнути гнучкі тематичні Л-системи, які можуть бути легко адаптовані для потреб кінцевого користувача, ефективно підтримувати аналітичні процеси, необхідні для вирішення прикладних завдань.

Ключові слова: реабілітачія, трансдисиипінарна інтеграчія, онтологія, лексикографічна система, аналіз даних.
\end{abstract}

Вступ. Проблема реабілітації хворих під час пандемії COVID-19 спричиненої вірусом SARS$\mathrm{CoV}-2$ на сьогодні є надзвичайно актуальною не тільки в Україні, а й у всьому світі. Наслідками перенесеної хвороби є цілий комплекс постковідних синдромів, серед яких значна частина належать до психічних розладів. Методики ж реабілітації хворих після перенесеної хвороби COVID-19 на сьогодні, у більшості випадків $€$ не розробленими. На сьогодні по всьому світові ведуться лише відповідні дослідження. Так вчені Оксфордського університету в одному 3 масштабних досліджень дійшли висновку, що в пацієнтів, які перехворіли на COVID-19, психічні розлади зберігаються понад 90 днів [1]. За даними науковців з Вуханя [2] найчастіше постковідними розладами $є$ тривога, депресія, астенія. Так, за цими даними близько $75 \%$ пацієнтів мають прояви хоча б одного із зазначених симптомів протягом не менше ніж півроку (i при цьому у цих людей негативний ПЛР-тест), а 25\% постковідних хворих мають усі три синдроми. Подібні результати отримують й інші вчені. Ризик депресії у досліджуваних, що перехворіли на COVID-19 значно перевищує показники досліджуваних з контрольної групи [3].

Таким чином питання реабілітації психічних розладів у хворих після COVID-19 $є$ на сьогодні однією із найактуальніших проблем у світі.

Як показує практика перелічених, а також багатьох інших досліджень, вивчення питань реабілітації постковідних хворих потребує аналізу великої кількості розподілених джерел даних. При цьому зазначена розподіленість $є$ не тільки просторовою, а й темпоральною. Дані для аналізу, в багатьох випадках, належать до різних предметних галузей, 
тобто є трансдисциплінарними.

В Україні питання, які стосуються реабілітації знаходяться в стадії розробки. Наприклад, документ, що регулює порядок організації надання реабілітаційної допомоги (постанова Кабінету Міністрів України «Питання організації реабілітації у сфері охорони здоров'я») в Україні ще знаходиться на етапі узгодження.

Таким чином виникає проблема створення систем 3 підтримки досліджень в галузі реабілітації, які би враховували велику кількість неоднорідних даних та граничних умов, що можуть змінюватися.

Одним iз механізмів створення таких інформаційних системє принцип відкритих онтологій, який зараз рекомендується провідними країнами світу для забезпечення семантичної інтеграції розподілених інформаційних систем різного типу. Ефективність зазначеної інтеграції обумовлює необхідність існування умови узгодженості, які накладаються на активні інформаційні процеси, що й визначає мережецентричність.

Реалізація вказаної умови узгодженості можлива 3 використанням лінгвістичних структур, які здатні забезпечити узгодженість взаємодії інформаційних процесів. Такими структурами є лексикографічні системи. Саме 3 допомогою таких систем можливо забезпечити умову узгодженості за рахунок врахування семіотичних та семантичних особливостей кожної предметної галузі. Серед таких систем можна виділити особливий клас онтологокерованих лексикографічних систем, які для семантичних одиниць різних предметних галузей реалізують їх трансдисциплінарну інтеграцію.

Мета дослідження полягає в розробленні технології спрямованої на вирішення проблеми інтеграції розподілених трансдисциплінарних даних в галузі фізичної та реабілітаційної медицини шляхом використання теорії лексикографічних систем та онтологічного підходу.

Матеріали i методи. Дослідження базується на корпусних лексикографічних технологіях [4] та теорії, архітектурі й системотехніці лексикографічних систем [5, 6]. Воно спрямоване на вирішення проблеми інтеграції розподілених інформаційних систем шляхом використання теорії лексикографічних систем для моделювання онтологокерованої Л-системи [7]. IIÏ архітектуру описано в термінах теорії Л-систем на концептуальному, внутрішньому та зовнішньому рівнях. Методологічною основою корпусних лексикографічних технологій $є$ теорія семантичних станів [8], на основі якої здійснюється семантико-синтаксичний аналіз природномовних об'єктів в трансдисциплінарних $[9,10]$ даних.

Л-систему розглядатимемо як певним чином семіотично та семантично організоване інформаційне середовище, в якому реалізується певна множина лексикографічних ефектів. Конструктивною властивістю лексикографічного ефекту $\epsilon$ індуктивність множини елементарних інформаційних одиниць (ЕIO), що предметно складають інформаційне середовище.

Відповідно до інформаційної інтерпретації процесів сприйняття [5], Л-система оперує результатом рецепції певним суб'єктом деякої предметної галузі (ПГ), що веде до генерації ЕІО. Дана множина є результатом процесу (1)

$$
I_{D}=I^{5}(D) \text {, }
$$

де $I_{D}$ - множина EIO; D - ПГ; $I^{5}-$ функція, реалізує власне процес рецепції ПГ суб'єктом $S$.

Онтологічна Л-система $\epsilon$ особливим випадком Л-системи, в якому ЕIO задаються 3 допомогою онтологій предметної галузі [11, 12], кожна 3 яких може бути представлена 3 допомогою впорядкованих трійок [13]:

$$
O=\left(I_{O}, R_{O}, V_{O}\right)
$$

Де $I_{O}-$ множина ЕIO, представлених в онтології в якості об'єктів; $R_{O}$ - множина створених експертом зв'язків між ЕIO; $V_{o}-$ множина описів ЕIO, що задаються атрибутами об'єктів.

Оскільки в мовленнєвому потоці онтологічна природа мови виступає неподільною на окремі складові частини, які $€$ в концептуальних [14] представленнях, то необхідним $є$ використання комплексних («інтегрованих») моделей мовних явищ, тобто інтеграції Л-систем, у вигляді яких вони представлені. Л-системи, таким чином, знаходяться в лексикографічному середовищі, яке $\epsilon$ адаптованим до процесів інтегрування різних лексикографічних систем і містить необхідні засоби та конструктиви для здійснення інтеграційних процесів.

Структура Л-середовища є зручним формальним об'єктом для формування складних лексикографічних конструкцій, які поєднують в одне ціле багато окремих різнорідних Л-систем (неоднорідних за всіма рівнями архітектури - концептуальним, внутрішнім і зовнішнім). Під інтеграцією Л-систем як інформаційних систем розуміємо досягнення можливості одночасного та спільного використання кількох інформаційних систем як єдиного цілого.

Інтеграція Л-систем під час індексації ресурсів типу «Big Data» відбувається наступним чином. Спочатку будується допоміжна Л-система, яка складається 3 таких елементів: знакові системи, структури та процеси рекурсивної редукції всіх Л-систем, що інтегруються. Далі спрацьовує спеціальнасемантичнапроцедура SEM, яказабезпечує ототожнення елементів структури, що збігаються бодай для двох систем 3 множини Л-систем (data sources), що інтегруються. Ця процедура здійснює ототожнення не лише імен семантично тотожних атрибутів, наявних у різних Л-системах, але й відповідних областей їхніх значень (контекстів). При цьому можливі різні випадки перетинів структур, що належать до різних Л-систем. У результаті одержуємо Л-систему зі знаковою системою, яка є об'єднанням знакових систем Л-систем, що інтегруються та відповідною структурою, одержаною описаним вище способом. 
Створення зазначеного Л-середовища у системі TISP реабілітаційного профілю забезпечується застосуванням спеціалізованих технологій онтологокерованого веб- чи інтранет кравлінгу. Підсистема кравлерів $€$ тісно інтегрованою із корпусною системою, системою індексації та полімовною синонімічною зоною. Кравлери, як i корпусна система, $\epsilon$ віртуалізованими лексикографічними агентами, тобто $є$ різновидом лексикографічних систем [4].

Архітектура онтологокерованої Л-системи [15] складається 3 двох підсистем, серверноінформаційної підсистеми пошуку та систем презентації на основі браузера, які працюють паралельно. Обидві підсистеми характеризуються тим, що вони використовують онтології як середовище для зберігання всіх видів інформації. Компонентам підсистем є (рис. 1). Кравлер (Crawler) використовується для збору документів з мережевого середовища. Цей компонент використовує стандартні мережеві протоколи (HTTP/HTTPS, FTP/SFTP тощо). Екстрактор тексту (Text Extractor) використовує спеціалізовані бібліотеки, щоб витягти фактичний текстовий вміст з документів 3 складним форматом, як HTML. Lexeme Extractor створює структури 3 формою (2) і виконує класифікацію класифікації на них, використовуючи словник (Dictionary), представлений у вигляді онтології. Екстрактор термінів (Term Extractor) виконує трансформацію на основі онтологічної бази правил (Rule Database), яка описує загальні шаблони мови, що можуть бути використані в тексті для визначення різних відношень між термінами. Ontology Builder - модуль, який створює онтологію у вигляді XML-файла (або будь-якого іншого формату, який підтримується підсистемою презентації інформації).

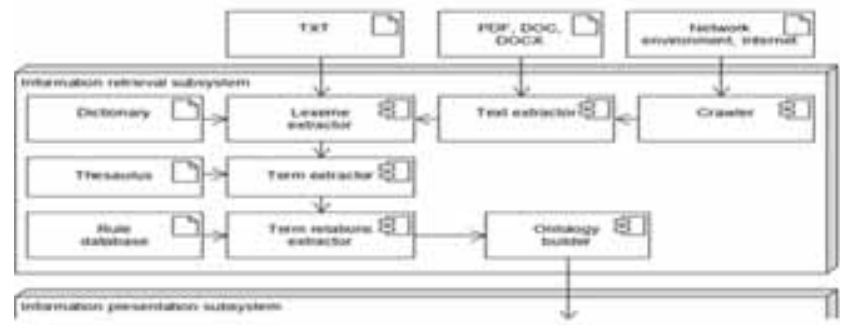

Рис. 1. - Архітектура онтологокерованої Л-системи

Результати. Описаний підхід дає можливість створити необхідне середовище для обробки та збереження інформаційних ресурсів у галузі фізичної та реабілітаційної медицини (ФРМ) та здійснити його індексування. Засоби індексування ФРМ забезпечують відображення трансдисциплінарних семантично пов'язаних контекстів в результаті обміну інформацією між розподіленими трансдисциплінарними інформаційними ресурсами (джерелами Big Data). Система індексування інформаційних ресурсів у галузі ФРМ акумулює функціональні можливості сервісів інших інформаційно-лексикографічних систем [16], а саме - електронної бібліотеки, граматичного словника [17], інтегрованої лексикографічної системи “Словники України” [18], а також функцій повнотекстового пошуку. Кожен інформаційний ресурс, повнотекстовий індекс якого створюється, утворює підкорпус, який, у свою чергу, $\epsilon$ лексикографічною системою (Л-системою) та $є$ відображенням першоджерела даних (source of data), яке також, відповідно, $є$ Л-системою.

Для створення колекції мережевих текстів у галузі ФРМ було створено онлайн сховище документів у приватній хмарині із застосуанням сервісів NEXTCLOUD (рис. 2) розміром 1,2 Гб за такими напрямками: МКФ (Міжнародна класифікації функціонування, обмеження життєдіяльності та здоров'я (МКФ) [19]), Біла книга (Біла книга фізичної i реабілітаційної медицини [20]) та пов'язані 3 нею документи, Офіційні документи з реабілітації (Закони, Накази МО3 тощо) також в окремому підрозділі розміщено статті, книги, журнали, звіти, дисертації. Також до сховища внесені деякі документи методично-навчального характеру з ФРМ.

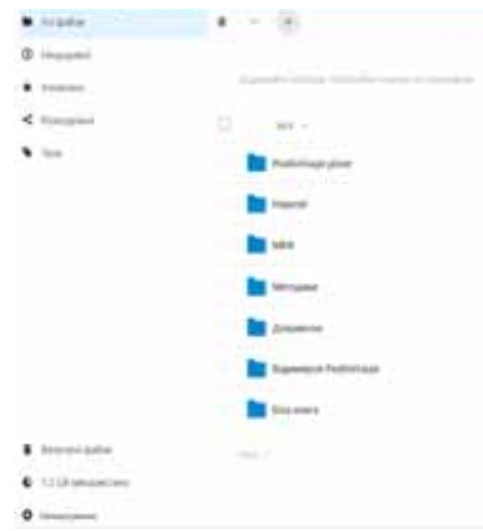

Рис. 2 - Сховище документації в галузі ФРМ

Створена колекція мережевих текстів у галузі ФРМ інтегрована із системою відображення онтологічної інформації у галузі ФРМ у кабінетах користувачів та може бути використана для досліджень (рис. 3).

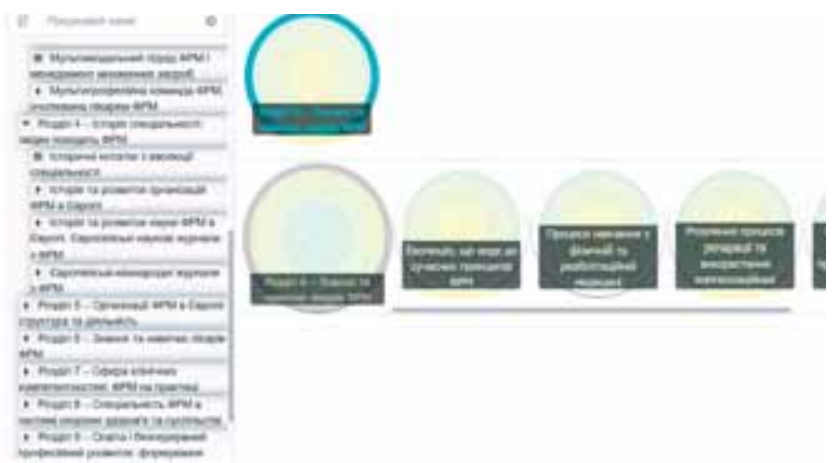

Рис. 3 - Система відображення онтологічної інформації у галузі ФРМ у кабінетах користувачів

Приклад пошукового запиту для дослідження концепту «знання та навички лікарів» в галузі ФРМ наведено на рис. 4. 

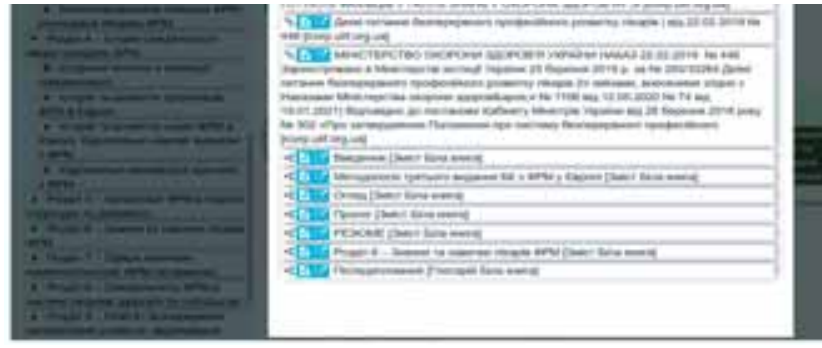

Рис. 4 - Система відображення онтологічної інформації у галузі ФРМ у кабінетах користувачів.

Використання колекції мережевих текстів у галузі ФРМ

За результатом запиту, наприклад, можна з'ясувати про які «знання та навички лікарів» в галузі ФРМ йде мова у наказах MO3 (рис. 5).
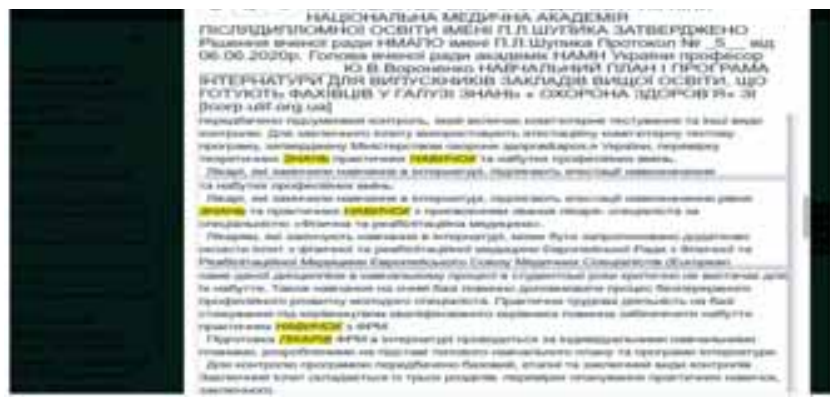

Рис. 5 - Система відображення онтологічної інформації у галузі ФРМ у кабінетах користувачів. Використання колекції мережевих текстів у галузі ФPM

Обговорення. Необхідність враховувати велику кількість неоднорідних даних та граничних умов, що можуть змінюватися під час створення систем 3 підтримки досліджень в галузі реабілітації ускладнюватиме процес надання реабілітаційної допомоги. При цьому необхідним $є$ створення систем 3 інтерактивним доступом до великих обсягів розподіленої інформації. Це дослідження пропонує автоматизувати процес відображення трансдисциплінарних семантично пов'язаних контекстів в результаті обміну інформацією між розподіленими трансдисциплінарними інформаційними ресурсами значно спрощуючи його і підвищуючи його ефективність.

Висновки. У ході дослідження. створено перспективний підхід до обробки великих масивів слабко i неструктурованих документів, що дало можливість здійснити моделювання онтологокерованоїЛ-системи на основі онтологічного підходу.

Описана архітектури онтологокерованих Л-систем дозволяє швидко розгорнути гнучкі тематичні Л-системи, які можуть бути легко адаптовані для потреб кінцевого користувача, ефективно підтримувати аналітичні процеси, необхідні для вирішення прикладних завдань.

Результатом проєктування такої системи є веборієнтований користувацький інтерфейс, який забезпечує інтерактивний доступ до великих обсягів розподіленої інформації в інформаційно-аналітичній системі супроводження процесів реабілітації при пандемії (TISP).

Перспективи подальших досліджень. У подальшій роботі планується розширення системи документів, що використовується для створення системи. При цьому важливим $є$ оцінювання ступеня подібності досліджуваних контекстів та виокремлення необхідних концептів. Таким чином в ході подальшої роботи планується створення використання елементів семантичного індексування та індексування на основі визначення метрики подібності - функції відстані між двома словами, що дозволяють оцінити ступінь їхньої подібності в даному контексті.

Додаткова інформація. Дослідження виконано при підтримці гранту Національного фонду досліджень України за договором від 07.05.2021 р. № 159/01/0245 «Трансдисциплінарна інтелектуальна інформаційно-аналітична система супроводження процесів реабілітації при пандемії (TISP)».

\section{Список літератури}

1. Maxime Taquet, John R Geddes, Masud Husain, Sierra Luciano, Paul J Harrison 6-month neurological and psychiatric outcomes in 236379 survivors of COVID-19: a retrospective cohort study using electronic health records. The Lancet Psychiatry. 2021. Vol. 8, No. 5, P. 416-427. DOI: 10.1016/S2215-0366(21)00084-5.

2. Chaolin Huang, Yeming Wang, Xingwang Li, et al. Clinical features of patients infected with 2019 novel coronavirus in Wuhan, China. The Lancet Psychiatry. 2020. Vol. 395, No. 10223. P. 497-506. DOI: 10.1016/S01406736(20)30183-5.

3. Qi Mei, Fei Wang, Amy Bryant, Li Wei, Xianglin Yuan, Jian Li. Mental health problems among COVID-19 survivors in Wuhan, China. World Psychiatry. 2020. Vol. 20, No. 1, P. 139-140. DOI: 10.1002/wps.20829.

4. Лінгвістично-інформаційні студії: праці Українського мовно-інформаційного фонду НАН України: Корпусна та когнітивна лінгвістика / Широков В. А., Надутенко М.В. та ін. Т. 4. Київ: Український мовно-інформаційний фонд НАН України. 2018. 280 с. DOI: 10.33190/978-96602-8683-2/8688-7. ISBN 978-966-02-8688-7.

5. Лінгвістично-інформаційні студії: праці Українського мовно-інформаційного фонду НАН України: Наукова парадигма та основні мовно-інформаційні структури / Широков В. А та ін. Т. 1. Київ: Український мовноінформаційний фонд НАН України. 2018. 271 с. DOI: 110.33190/978-966-02-8683-2/8684-9. ISBN 978-966-028684-9.

6. Palagin A. V., Shyrokov V. A. Principles of cognitive lexicography. Informational theories \& application. 2000. Vol. 9. No. 2. P. 43-51.

7. Palagin A., Kryvyi S., Petrenko N. Knowledge-oriented information systems with the processing of naturallanguage objects: basics of methodology and architectural 
and structural organization. Control Syst. Comput. 2009. P. 42-55.

8. Широков В.А. Інформаційна теорія лексикографічних систем. Київ: Довіра; 1998. 330 с.

9. Shyrokov V.A. Language. Information. System: Transdisciplinarity in Linguistics. Palmarium Academic Publishing. 2017. 280 p. ISBN 978-3-659-72403-9. Available from: https://isbnsearch.org/isbn/9783659724039. Accessed: September 05, 2021.

10. Stryzhak O., Prychodniuk V., Podlipaiev V. Model of Transdisciplinary Representation of GEOspatial Information. In: Lecture Notes in Electrical Engineering. Cham : Springer. 2019. P. 34-75.

11. Широков В.А, Потапова Е.В. Онтология предметной области как лексикографическая система особого типа. Kazanskaja nauka. 2012. Вып 12. C. 209-213.

12. Shyrokov V., Ostapova I., Nadutenko M., Verbynenko Yu. Ontologized lexicographical systems in modern terminography. Cognitive Studies | Etudes cognitives. Warsaw. 2016. P. 90-99.

13. Pryhodinuk V., Stryzhak O. Multiple characteristics of ontological systems. Math. Model. Econ. 2017. P. 47-61.

14. Широков В.А, Шевченко Л.Л. Дослідження концептів у сучасній лінгвістиці та системній концептографії. Науковий часопис Національного педагогічного університету імені М.П. Драгоманова: Проблеми граматики і лексикологї. 2011. Вип. 8. С. 387-392.

15. Tsichritzis D., Klug A. The ANSI/X3/SPARC DBMS framework report of the study group on database management systems. Inf. Syst. 1978. Vol. 3. P. 173-191. https://doi.org/10.1016/0306-4379(78)90001-7.

16. Надутенко М.В. Загальний огляд та перспективи використання національних лінгвістичних цифрових ресурсів Українського лінгвістично-інформаційного фонду НАН України. URL: http://ekmair.ukma.edu.ua/ handle/123456789/17607 (дата звернення: 05.09.2021).

17. Virtual lexicographic laboratory «Dictionary of Ukrainian Language Online» (SUM-20). URL: https:// services.ulif.org.ua/expl/ (дата звернення: 11.10.2021).

18. Integrated lexicographic system (ILS) «Dictionaries of Ukraine». URL: https://lcorp.ulif.org.ua/dictua/ (дата звернення: 11.10.2021).

19. World Health Organisation. International Classification of Functioning, Disability and Health: ICF. Geneva : WHO. 2001. 299 p.

20. White Book on Physical and Rehabilitation Medicine (PRM) in Europe. Chapter 7. The clinical field of competence: PRM in practice. European Journal of Physical and Rehabilitation Medicine. 2018. Vol. 5. No. 2. P. 230-260 DOI: https://doi.org/10.23736/S1973-9087.18.05151-1.ף

\section{References $\Phi$}

1. Maxime Taquet, John R Geddes, Masud Husain, Sierra Luciano, Paul J Harrison 6-month neurological and psychiatric outcomes in 236379 survivors of COVID-19: a retrospective cohort study using electronic health records. The Lancet Psychiatry. 2021; 8 (5): 416-427. DOI: 10.1016/ S2215-0366(21)00084-5.

2. Chaolin Huang, Yeming Wang, Xingwang Li, et al. Clinical features of patients infected with 2019 novel coronavirus in Wuhan, China. The Lancet Psychiatry. 2020; 395 (10223): 497-506. DOI: 10.1016/S0140-6736(20)30183-5.
3. Qi Mei, Fei Wang, Amy Bryant, Li Wei, Xianglin Yuan, Jian Li. Mental health problems among COVID-19 survivors in Wuhan, China. World Psychiatry. 2020; 20 (1): 139-140. DOI: 10.1002/wps.20829.

4. Shyrokov V.A., Nadutenko M.V., et al. Lingvistychnoinformacijni studii': praci Ukrai'ns'kogo movnoinformacijnogo fondu NAN Ukrai'ny: Korpusna ta kognityvna lingvistyka [Lingua-information studies: Works of the Ukrainian Lingua-Information Fund: Corpus and cognitive linguistics]. Vol. 4. Kyiv: Ukrainian LinguaInformation Fund; 2018. 280 p. DOI: 10.33190/978-966-028683-2/8688-7. ISBN 978-966-02-8688-7. (in Ukrainian).

5. Shyrokov V.A., et al. Lingvistychno-informacijni studii': praci Ukrai'ns'kogo movno-informacijnogo fondu NAN Ukrai'ny: Naukova paradygma ta osnovni movnoinformacijni struktury [Lingua-information studies: Works of the Ukrainian Lingua-Information Fund: Scientific paradigm and basic lingua-information structures]. Vol. 1. Kyiv: Ukrainian Lingua-Information Fund; 2018. 271 p. DOI: 110.33190/978-966-02-8683-2/8684-9. ISBN 978966-02-8684-9. (in Ukrainian).

6. Palagin A. V., Shyrokov V. A. Principles of cognitive lexicography. Informational theories \& application. 2000; 9 (2): 43-51.

7. Palagin A., Kryvyi S., Petrenko N. Knowledge-oriented information systems with the processing of naturallanguage objects: basics of methodology and architectural and structural organization. Control Syst. Comput. 2009: 42-55.

8. Shyrokov V.A. Informacijna teorija leksykografichnyh system [Information theory of lexicographic systems]. Kyiv: Dovira; 1998. 330 p. (in Ukrainian).

9. Shyrokov V.A. Language. Information. System: Transdisciplinarity in Linguistics. Palmarium Academic Publishing. 2017. 280 p. ISBN 978-3-659-72403-9. Available from: https://isbnsearch.org/isbn/9783659724039. Accessed: September 05, 2021.

10. Stryzhak O., Prychodniuk V., Podlipaiev V. Model of Transdisciplinary Representation of GEOspatial Information. In: Lecture Notes in Electrical Engineering. 2019; 34-75; Cham : Springer; 2019.

11. Shyrokov V.A., Potapova E.V. Ontology of the subject area as a lexicographic system of a special type. Kazanskaja nauka. 2012; 12: 209-213. (in Russian).

12. Shyrokov V., Ostapova I., Nadutenko M., Verbynenko Yu. Ontologized lexicographical systems in modern terminography. Cognitive Studies | Etudes cognitives. Warsaw. 2016: 90-99.

13. Pryhodinuk V., Stryzhak O. Multiple characteristics of ontological systems. Math. Model. Econ. 2017: 47-61.

14. Shyrokov V.A., Shevchenko L.L. Doslidzhennja konceptiv u suchasnij lingvistyci ta systemnij konceptografii' [Research of concepts in modern linguistics and system conceptography]. Naukovyj chasopys Nacional'nogo pedagogichnogo universytetu imeni M.P. Dragomanova: Problemy gramatyky i leksykologii'. 2011; 8: 387-392. (in Ukrainian).

15. Tsichritzis D., Klug A. The ANSI/X3/SPARC DBMS framework report of the study group on database management systems. Inf. Syst. 1978; 3: 173-191. https:// doi.org/10.1016/0306-4379(78)90001-7.

16. Nadutenko M.V. General overview and prospects of using national linguistic digital resources of the Ukrainian Lingua-Information Fund of the NAS of Ukraine. Available 
from: http://ekmair.ukma.edu.ua/handle/123456789/17607. Accessed: September 05, 2021. (in Ukrainian).

17. Virtual lexicographic laboratory «Dictionary of Ukrainian Language Online» (SUM-20). Available from: https://services.ulif.org.ua/expl/. Accessed: October 11, 2021.

18. Integrated lexicographic system (ILS) «Dictionaries of Ukraine». Available from: https://lcorp.ulif.org.ua/dictua/. Accessed: October 11, 2021.
19. World Health Organisation. International Classification of Functioning, Disability and Health: ICF. Geneva : WHO. 2001.299 p.

20. White Book on Physical and Rehabilitation Medicine (PRM) in Europe. Chapter 7. The clinical field of competence: PRM in practice. European Journal of Physical and Rehabilitation Medicine. 2018; 54 (2): 230-260 DOI: https://doi.org/10.23736/S1973-9087.18.05151-1.

\section{DEVELOPMENT OF A SYSTEM FOR ANALYZING TRANSDISCIPLINARY DATA IN THE FIELD OF PHYSICAL AND REHABILITATION MEDICINE (PRM)}

\section{Nadutenko M.V.}

Rehabilitation is an important component of the health care system. The problem of rehabilitation of patients during the COVID-19 pandemic caused by SARS-COV-2 virus is extremely relevant not only in Ukraine but also around the world. Methods of rehabilitation of patients after the COVID-19 disease, in most cases, are not designed. In Ukraine, one of the tasks outlined in the approved Human development strategy is the introduction of an effective rehabilitation system based on unified standards. However, the regulatory framework associated with rehabilitation issues is in the stage of formation. Thus, there is a problem of creating systems for supporting research in the field of rehabilitation that would take into account a large number of heterogeneous data and limiting conditions that may vary.

One of the mechanisms for the creation of such information systems is the principle of open ontologies, which is now recommended by the leading countries of the world to ensure the semantic integration of distributed information systems of different types.

The aim of the study is to develop the technology aimed at solving the problem of integrating distributed transdisciplinary data in the field of physical and rehabilitation medicine based on an ontological approach.

Materials and Methods. Most transdisciplinary data in physical and rehabilitation medicine are documents written in natural language. Ontological nature of language, in the speech flow, acts indivisible to separate components that are in conceptual representations, then for a formalized description of an expert-rehabilitation, we need to use the integrated models of linguistic phenomena and corpora technologies. The methodological basis of corpora lexicographic technologies is the theory of semantic states, on the basis of which semantic and syntactic analysis of natural-language objects in transdisciplinary data is carried out.

Results. Described approach allows to create a necessary environment for processing and indexing information resources in the field of physical and rehabilitation medicine. FRM indexing means provide a mapping of transdisciplinary semantically related contexts as a result of the exchange of information between distributed transdisciplinary information resources. The system of indexing information resources in the FRM accumulates the functionality of services of other information-lexicographic systems, namely: electronic library, grammar dictionary, as well as functions of full-text search.

Conclusions. The conducted research allows the creation of technology aimed at solving the integration of distributed transdisciplinary data in the field of physical and rehabilitation medicine based on ontological approach. The indicated approach allows to quickly deploy flexible thematic L-systems that can be easily adapted for the needs of the end user, effectively support analytical processes, necessary to solve applied tasks.

Keywords: rehabilitation; transdisciplinary integration; ontology; lexicographic system, data analysis. 